\title{
Yield and nutritive value of hay from five tropical grasses at three harvesting intervals'
}

\author{
Angel V. Méndez-Cruz, Victor Siberio-Torres, John Fernández- \\ van Cleve, Eleanor Fontanet and Gumersindo Ramirez-Oliveras
}

\begin{abstract}
Five Iropical grasses, Cynodon dacfylon (coastcross), Cynodon nlemfuensis (star grass), Cynodon plectostachyus (callie), Digitaria pentzii (slenderstem), and Panicum maximum (guinea) PRPI 12917, were planted for hay production on a Vertisol soil with irrigation in the lajas valley. On the basis of all factors studied, guinea, star grass and slenderstem, harvested at 45-day intervals (DI), are the best for hay production under adequate irrigation and fertilizer use in Vertisol soils in the southern coast of Puerto Rico. The forages were harvested at 35-, 45- and 55 DI. The highest yields of hay were obtained from guinea at 35- and $45(2069$ and $2901 \mathrm{~kg} / \mathrm{ha}$, respectively), and from slenderstem at the $55-\mathrm{DI}(3397 \mathrm{~kg} / \mathrm{ha})$. The highest crude protein content was obtained with star grass at the $35-\mathrm{DI}(18.6 \%)$ and with callie at $45-$ and $55-\mathrm{DI}$ (14.0\% and $11.5 \%$, respectively). Crude protein yield at 35-DI was highest for star grass $(356 \mathrm{~kg} / \mathrm{ha})$. At $45-$ and 55-Dl slenderstem was higher ( 383 and $384 \mathrm{~kg} / \mathrm{ha}$, respectively). The highest digestion coefficients (DC) at the 45- and 55-DI were obtained with guinea (63.0 and 59.0, respectively), although not significantly different $(P>0.05)$ from those of slenderstem and coastcross. At a 35-DI, coastcross averaged the highest DC $(64.3 \%)$. The highest voluntary intake at the 35-DI was observed with coastcross (2.8\% of body weight daily), but not more $(P>0.05)$ than with slenderstem or star grass. At the 45 - and 55-DI, the highest voluntary intake was observed with star grass and guinea ( $2.4 \%$ and $2.3 \%$ of body weight daily, respectively). The highest relative nutritive value (digestibility $x$ voluntary intake) was obtained with coastcross (1.81) at the 35-DI and with guinea at the 45- and 55-Di (1.51 and 1.36 , respectively).
\end{abstract}

\section{INTRODUCTION}

Forage programs used in most dairy and beef cattle operations in Puerto Rico are based on grazing or green chopping of various grass species, notably star grass, pangola, guinea, merker, and several native species. As in all tropical countries, seasonal variations in forage productivity and nutritive value are reflected in varying animal performance. During the seasons of maximum growth the forages produced in greater dry matter quantities are physiologically more mature at a given harvest

'Manuscript submitted to Editorial Board 16 December 1986.

${ }^{2}$ Associate Animal Husbandman, Research Assistant, Research Assistant, Animal Industry Department; Assistant Statistician; and Assistant Agronomist, Department of Agronomy and Soils, Agricultural Experiment Station, University of Puerto Rico, Rio Piedras, P. R. 
interval, but used less efficiently by animals. These forages are often produced in excess of the herd demand and are wasted. Conversely, during periods of slow plant growth there is often insufficient forage to permit maximum intake by the animals. The result is greater reliance on concentrate feeds and higher production cost of milk and meat. Forage preservation is one obvious means of overcoming this seasonal imbalance between need and availability.

Preservation of surplus forage as hay, a standard procedure in many temperate countries, was little used in the past in Puerto Rico. However, commercial hay production on the island has gradually increased to the point of being an appreciable commodity; thus, research into optimum procedures for hay production and utilization is justified. Among the matters requiring investigation is selection of the most useful forage species $(3,12)$, a choice which should be based on knowledge regarding yield, ease of field curing and nutritive value of the hay produced. Another key factor is harvest interval, with which forage yield varies directly, whereas nutritive value varies inversely $(7,12)$.

Previous research into these questions has been conducted in Puerto Rico, but not under conditions comparable to those of commercial practice, since the forages were hand harvested $(2,4,10)$. Therefore, the present experiment was initiated with the objective of evaluating hay produced mechanically from five grass species at three different harvest intervals. The criteria include dry matter and crude protein yields and contents, voluntary consumption by steers and in vivo digestibility.

\section{MATERIALS AND METHODS}

A three-hectare field subdivided into five equal plots was planted with the following grasses: Cynodon dactylon (Coastcross), Cynodon nlemfuensis (star grass), Cynodon plectostachyus (Callie), Digitaria pentzii (slenderstem), and Panicum maximum (guinea PRPI 12917). The study was conducted in the Lajas Valley in a Vertisol soil (very fine, montmorrillonitic, isohyperthermic) which had a $\mathrm{pH}$ of 6.5 and was low in available phosphorus.

Before land preparation, weeds were killed with glyphosate $(0.41 \%$ isopropylamine salt). The soil was disc-plowed, harrowed twice, landplaned and furrowed to a depth of $15 \mathrm{~cm}$. The forages were planted from May to mid-June 1977. Vegetative material was placed in the furrows and partially covered with soil. Fertilizer of 15-5-10 analysis was broadcast at the rate of $545 \mathrm{~kg} / \mathrm{ha}$ after planting. The area was sprayed with $7.5 \mathrm{~kg} / \mathrm{ha}$ of the preemergent herbicide (Princep $80 \mathrm{~W}$ ) and thereafter

'Trade names in this publication are used only to provide specific information. Mention of a trade name does not constitute a warranty of equipment or materials by the Agricultural Experiment Station of the University of Puerto Rico, nor is this mention a statement of preference over other equipment or materials. 
irrigated by flooding, except in the case of buffel, where sprinkle irrigation was used. All plots were cut 11 October 1977, and a harvesting schedule was prepared for cutting at 35-, 45- and 55-day intervals. The haybine was adjusted to cut at $5 \mathrm{~cm}$ above soil surface. First scheduled harvests were in November at 35-day intervals and thereafter at indicated intervals over a period of 4.5 years until May 1982 . Frequent rains from August through early October prevented hay making; therefore, to maintain cutting intervals, the forage was used as gxeen chop feed during this period.

The cut forage was left in the sward for 2 or 3 days and raked into windrows. The latter were turned daily until ready for baling. In the event of rain, the curing period was prolonged. Moisture content of the harvested grasses in the field was measured at random spots with a 9-volt-DC moisture meter. The crop was baled at 18 to $20 \%$ moisture with a machine adjusted to make bales approximately $60 \mathrm{~cm} \times 45 \mathrm{~cm} 38$ $\mathrm{cm}$.

From every baling for each grass, a sample of 10 to 15 bales/plot was weighed and recorded. The harvested forages were then stored for protection against unfavorable weather conditions and used within 6 weeks.

Following each harvest, a 15-5-10 fertilizer was broadcast at a rate of $715 \mathrm{~kg} / \mathrm{ha}$. Borders were kept free of weeds with glyphosate, and flooding irrigation was applied as required during growing intervals. Uniform samples were taken from random bales and were oven-dried at $60^{\circ} \mathrm{C}$ to determine moisture content. These were then ground in a Wiley mill through a $1 \mathrm{~mm}$ sieve.

Crude protein content of the hay samples, for all grasses at each cutting interval, was determined by the standard Kjeldahl procedure (1). Voluntary feed consumption and in vivo dry matter digestibility were determined for hay collected from one mid-experiment cutting. We used $340-390 \mathrm{~kg}$ Holstein steers places in metabolic cages, according to the total collection procedure (5).

Data collected on green forage yield (GFY), dry matter yield (DMY), dry matter content (DMC) and crude protein yield (CPY) were statistically evaluated by analysis of variance, according to a complete randomized design with a 5 (grasses) $\times 3$ (cutting intervals) $\times 5$ (years) factorial arrangement of treatments. Data from the in vivo trials (voluntary intake, VI; dry matter digestibility, DMD; relative nutritive value, RNV) were subjected to analysis of variance according to a complete randomized design with a 5 (gxasses) $\times 3$ (cutting intervals) factorial arrangement of treatments, with four replicates (animals) per treatment. Treatment means were compared by Duncan's new multiple range test (14). 


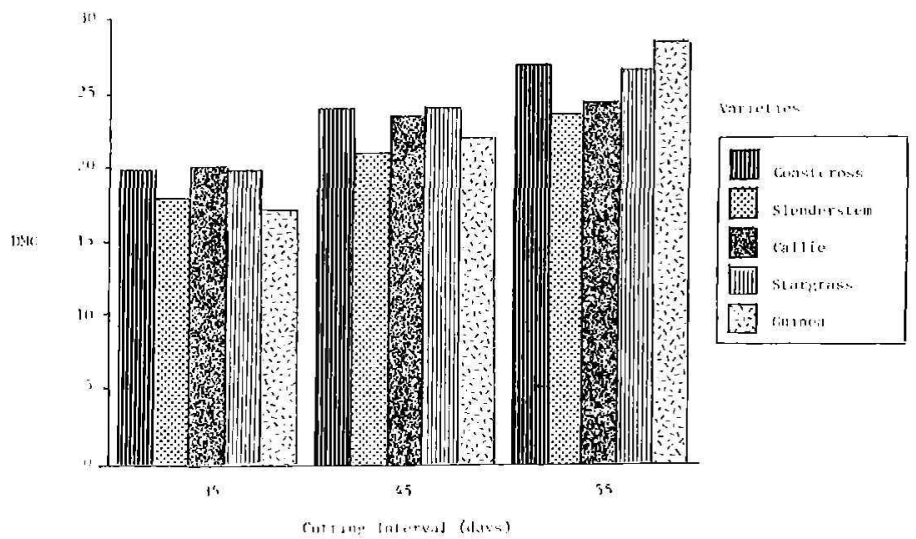

Fic. 1.-Average dry matter content (DMC) of five tropical forage grasses at three harvesting intervals (35-, 45- and 55-DI).

\section{RESULTS AND DISCUSSION}

The highest dry matter content (DMC; fig. 1) was obtained from guinea at the 55-DI (28.3\%). However, this amount was not significantly different $(\mathrm{P}>0.05)$ from that of stargrass or coasteross (26.4 and $26.9 \%$, respectively). At the 35- and 45-DI values of DMC obtained from Callie, Coasteross and star grass (19.9, 19.8 and $19.8 \%$, respectively and 23.4, 23.8 and $23.9 \%$, respectively), were not different $(\mathrm{P}>0.05)$. Arroyo and Oporta (2) reported similar DMC from merker and guinea grass hay.

The highest dry matter yield (DMY; table 1) was obtained from slenderstem at the 55 -DI ( $3400 \mathrm{~kg} / \mathrm{ha}$ per cut), but this did not differ significantly ( $P>0.05)$ from the values for coastcross, star grass and guinea $(3396,3383$ and $3280 \mathrm{~kg} / \mathrm{ha}$ per cut, respectively). At the 35 - and the 45-DI the highest DMY was obtaned with guinea (2069 and $2901 \mathrm{~kg} / \mathrm{ha}$ per cut, respectively), even though these yields were not significantly different from those of slenderstem (1949 and $2761 \mathrm{~kg} / \mathrm{ha}$ per cut, respectively). Hay dry matter yield depends upon a number of factors. Inherent difference in yield capacity exist both among forage species and among different varieties of the same species, as shown by Vélez et al. (15) for guinea and buffel varieties, and Machado and Pedraza (6) for Cynodon sp. and Digitaria sp. A large variation in forage development was observed between cuttings within years. Schank et al. (11) compared tropical grass forage species and observed growth fluctuations, within the same variety, at different cutting intervals. The lowest DMY in this study was obtained with callie. This finding agrees with that of Rivera 
TABLE 1.-Average dry forage yield. (DRF) and crude prolein yield (CPY) of five tropical faroge frases at three havesting intervals (35-, 45- and 55-day)

\begin{tabular}{|c|c|c|c|c|c|c|}
\hline \multirow[b]{2}{*}{ Varieties } & \multicolumn{2}{|c|}{$35-\overline{D I}$} & \multicolumn{2}{|c|}{$45-\overline{D I}$} & \multicolumn{2}{|c|}{ 55-DI } \\
\hline & DRF & CPY & $\mathrm{DFY}$ & CPY & DFY & CPY \\
\hline & kg/halcewt & $\mathrm{kg} / \mathrm{hr}$ & kg/ha & kgtha & kg/hn & kg/ha \\
\hline Coastcross & $1832 b^{2}$ & $262 \mathrm{a}$ & 2582 & $293 \mathrm{~b}$ & 3397 a & 339 \\
\hline Slenderstem & 1949 a & $294 a$ & $2761 \mathrm{a}$ & $383 a$ & $3400 \mathrm{a}$ & $384 \mathrm{a}$ \\
\hline Callie & $1579 \mathrm{e}$ & $258 \mathrm{a}$ & 2143 & $300 \mathrm{~b}$ & $2274 \mathrm{~b}$ & 262 \\
\hline Stargrass & $1921 \mathrm{ab}$ & 356 & $2838 \mathrm{a}$ & $336 a$ & $3382 \mathbf{a}$ & $373 \mathrm{a}$ \\
\hline Guinea & 2069 a & $299 \mathrm{a}$ & 2901 a & $372 \mathrm{a}$ & $3280 \mathrm{a}$ & 307 \\
\hline Mean & 1870 & 294 & 2644 & 337 & 3146 & 325 \\
\hline Standard & & & & & & \\
\hline deviation & 201 & 45 & 151 & 45 & 230 & 31 \\
\hline
\end{tabular}

' Means per grass per harvest interval.

${ }^{2}$ Means in the same column followed by one or more letters in common do not differ significantly at the $5 \%$ probability level.

and Rodríguez (8), who reported callie as significantly inferior $(P<0.05)$ in dry matter yields to five other grasses during several years of research. In Cuba, bermuda grass outyielded several Digitaria species in dry matter (3).

The 35-, 45- and 55-day harvesting intervals averaged 10.4, 8.1 and 6.6 cuttings per year, respectively, which, in turn, yielded an estimated pooled mean of $19.5,21.4$ and 20.9 tons of DFY, respectively (table 2). Similar trends were observed regarding estimated DFY at the 35- and 45-DI as guinea (21.7 tons) was followed in order by slenderstem (20.3 t), star grass (20.0 t), coastcross (19.1 t) and callie (16.5 t). At the 55-DI, Coastcross and star grass showed some degree of persistency in DFY, even though not at the expected rate. At this interval, guinea ranked fourth (21.8 t), whereas coastcross and star grass recovered and averaged higher DFY (22.5 t each) than at other intervals. Performance of Coastcross was retarded by weed invasion which competed greatly during the first 4 weeks of regrowth.

The mean annual estimated CPYs (table 2) were 3.1, 2.6, and 2.2 tons for the 35-, 45- and 55-DI, respectively. The highest yield at the 35-DI was obtained with star grass $(3.7 \mathrm{t})$, but values for slenderstem and guinea were similar to the mean. At the 45-DI, the highest expected CPY was $3.1 \mathrm{t}$ for slenderstem, but at the 55-DI both star grass and slenderstem averaged $2.5 \mathrm{t}$. At these intervals the lowest estimated CPY were for guinea (2.2 and $2.0 \mathrm{t}$, respectively) and for callie $(2.4$ and $1.7 \mathrm{t}$, respectively):

\section{Crude Protein Content and Yield}

Mean crude protein content (CPC) of hays in this study were 15.6 , 12.8 and $10.6 \%$ for the $35-, 45-$ and $55-\mathrm{DI}$, respectively (fig. 2 ). The 
TAHLE 2.-Estimated annual dry matler and crude protein yields of five tropical forage grasses at three harvesting intervals (85-, 4.5- and 55-day)

\begin{tabular}{|c|c|c|c|c|c|c|c|c|}
\hline \multirow[b]{2}{*}{ Varieties } & \multicolumn{2}{|c|}{ 35-DI } & \multicolumn{2}{|c|}{ 45-DI } & \multicolumn{2}{|c|}{ 55-DI } & \multirow[b]{2}{*}{$\begin{array}{c}\begin{array}{c}\text { Mean DFY } \\
\text { (Tons) }\end{array} \\
\end{array}$} & \multirow[b]{2}{*}{$\begin{array}{r}\text { Mean } \\
\text { (Tons) }\end{array}$} \\
\hline & $\begin{array}{c}\text { DFY } \\
\text { (Tons) }\end{array}$ & $\begin{array}{c}\text { CPY } \\
\text { (Tons) }\end{array}$ & $\begin{array}{c}\text { DFY } \\
\text { (Tons) }\end{array}$ & $\begin{array}{c}\text { CPY } \\
\text { (Tons) }\end{array}$ & $\begin{array}{c}\text { DFY } \\
\text { (Tons) }\end{array}$ & $\begin{array}{c}\text { CPY } \\
\text { (Tons) }\end{array}$ & & \\
\hline Coasteross & 19.1 & 2.7 & 20.9 & 2.4 & 22.5 & 2.2 & 20.8 & 2.4 \\
\hline Slenderstem & 20.3 & 3.1 & 22.4 & 3.1 & 22.6 & 2.5 & 21.8 & 2.9 \\
\hline Callie & 16.5 & 2.7 & 17.4 & 2.4 & 15.1 & 1.7 & 16.3 & 2.3 \\
\hline Stargrass & 20.0 & 3.7 & 23.0 & 2.7 & 22.5 & 2.5 & 21.8 & 3.0 \\
\hline Guinea & 21.7 & 3.1 & 23.5 & 2.2 & 21.8 & 2.0 & 22.3 & 2.4 \\
\hline Mean & 19.5 & 3.1 & 21.4 & 2.6 & 20.9 & 2.2 & 20.6 & 2.6 \\
\hline
\end{tabular}

tendency for CPC to decrease as harvesting interval increased was observed in all species studied and agrees with the findings of Gutierrez et al. (4). At the 35-DI, the highest CPC (18.6\%) observed in star grass. Callie $(16.3 \%)$ surpassed $(\mathrm{P}<0.05)$ both coastcross $(14.3 \%)$ and guinea (14.5\%), but not slenderstem $(15.1 \%)$, whereas the latter three did not differ from each other $(\mathrm{P}>0.05)$. At the $45-\mathrm{DI}$, the $\mathrm{CPC}$ of slenderstem $(13.9 \%)$ and callie $(14.0 \%)$ exceeded $(\mathrm{P}<0.05)$ that of coastcross $(11.4 \%)$ and star grass (11.9\%), but not guinea $(12.8 \%)$. There were no differences $(P>0.05)$ among the latter three. At the 55-DI callie, star grass and slenderstem were higher $(\mathrm{P}<0.05)$ in $\mathrm{CPC}(11.5,11.3$ and $11.0 \%$, respectively) than coasteross (10.0\%) and guinea $(9.4 \%)$.

This study showed an average CPC of $12.2 \%$ for the three harvesting intervals in guinea. Arroyo and Oporta (2) compared chemical compo-

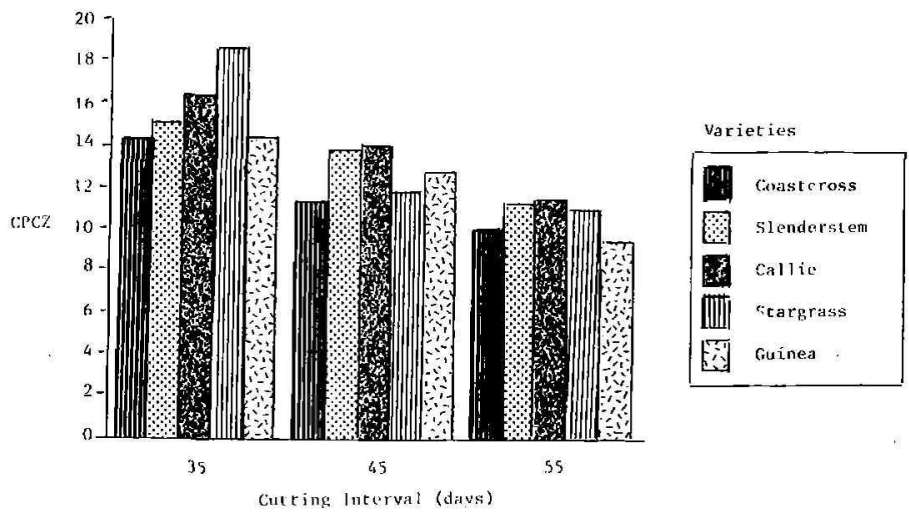

FYG. 2.-Average crude protein content $(\mathrm{CPC})$ of five tropical grasses harvested at three harvesting intervals (35-, 45- and 55-DI). 
nents of guinea and merker harvested at 30-, 45- and 60-DI and found that the average $\mathrm{CPC}$ of guinea $(7.8 \%)$ was significantly lower $(\mathrm{P}<0.05)$ than the mean CPC of merker (9.1\%). The average CPC obtained with slenderstem was $13.4 \%$, which is considerably higher than that reported by Gutiérrez et al. (4) with pangola harvested at 30-, 45- and 60-DI $(7.0 \%)$.

Nutritive value

Mean dry matter digestion coefficients (DMDC) observed across all cutting intervals were $62.3 \%, 59.5 \%$, and $56.0 \%$ for $35-$, 45 - and 55 -DI, respectively (table 3). All four of the other species were superior $(\mathrm{P}<0.05)$ to callie in DMDC at all cutting intervals (table 3). At 35-DI the highest digestibility was that of coasteross (64.3), whereas at both 45 - and 55-DI that of guinea was highest (63.1 and 59.2, respectively). At the latter two cutting intervals guinea surpassed $(P<0.05)$ star grass, but not coastcross or slenderstem.

Gutiérrez et al. (4) found that digestibility of pangola hay (51.8\%) was higher than that of star grass hay (50.2\%). Arroyo and Oporta (2) reported no dry matter digestibility differences between guinea $(48.4 \%)$ and merker hay $(51.9 \%)$, however, significant differences were observed among harvesting intervals of 30,45 , and 60 days (54.6, 47.6 and $48.2 \%$, respectively).

In ranking of hays of the different species according to voluntary intake relative to body weight VI was inconsistent at different harvest intervals (table 3). At 35-DI, the highest VI, that of coastcross (2.82), surpassed $(P<0.05)$ that of Callie (2.32) and guinea (2.35), but not that of slenderstem (2.42) or star grass (2.49). At 45-DI and 55-DI, coastcross was no longer outstanding in VI, but rather almost equal to the overall mean. Star grass had the highest VI $(2,43)$ at 45 -DI, but was not outstanding at the other two harvest intervals. Guinea was the leading species at 55-DI (2.30) and a close second at 45-DI (2.40), but below average (2.35) at 35-DI. Slenderstem was slightly below the overal mean of VI at each of the three harvest intervals and callie moreso. Yazman et al. (16) reported reduced dry matter intakes (DMI) of star grass hay harvested at $45-\mathrm{DI}(1.8 \% \mathrm{LVW})$ relative to that harvested at 30 -DI $(2.3 \%$ LVW) and attributed this to wide differences in CPC (12.8 vs $9.4 \%)$. Gutierrez et al. (4) found higher DMI of pangola hay (1.79\%) liveweight (LVW)) than that of star grass hay (1.50\% LVW). However, differences in DMI were not significant in hay harvested at 30-, 35- and 60-DI (4).

Relative nutritive value

The relative nutritive value (RNV) is a term suggested by Rohweder et al. (9). It is the daily consumption of digestible dry matter as a percentage of $L V W$, and expresses as a single figure overall forage quality when 
TABLE 3.-Mean digestion coefficient (DC), voluntary intake (VI) and relatine mutritive value (RNV) of five tropical forage grasses cut at three harvesting intervals and field cured as hay'

\begin{tabular}{|c|c|c|c|c|c|c|c|c|c|}
\hline \multirow[b]{2}{*}{ Varieties } & \multicolumn{3}{|c|}{$35-\mathrm{DI}$} & \multicolumn{3}{|c|}{$45-\mathrm{DI}$} & \multicolumn{3}{|c|}{ 55-DI } \\
\hline & DC & VI & RNV & DC & $\mathrm{VI}$ & RNV & $\mathrm{DC}$ & VI & RNV \\
\hline & \multicolumn{3}{|c|}{$\%$} & \multicolumn{3}{|c|}{$\%$} & \multicolumn{3}{|c|}{$\%$} \\
\hline Coasteross & $64.3 \mathrm{a}^{2}$ & $2.82 \mathrm{a}$ & $1.81 \mathrm{a}$ & $60.8 \mathrm{ab}$ & $2.33 a b$ & $1.42 \mathrm{ab}$ & $58.8 \mathrm{a}$ & $2.19 \mathrm{~b}$ & $1.29 \mathrm{a}$ \\
\hline Slenderstem. & $62.7 \mathrm{a}$ & $2.42 \mathrm{ab}$ & $1.52 \mathrm{bc}$ & $60.2 \mathrm{ab}$ & $2.29 \mathrm{bc}$ & $1.38 \mathrm{~b}$ & $57.3 \mathrm{ab}$ & $2.13 \mathrm{~b}$ & $1.22 \mathrm{~b}$ \\
\hline Callie & $57.6 \mathrm{~b}$ & $2.32 \mathrm{~b}$ & $1.34 \mathrm{bcd}$ & $54.3 \mathrm{c}$ & $2.20 \mathrm{c}$ & $1.20 \mathrm{e}$ & $51.8 \mathrm{c}$ & $2.08 \mathrm{c}$ & $1.08 \mathrm{e}$ \\
\hline Stargrass & $63.3 \mathrm{a}$ & $2.49 \mathrm{ab}$ & $1.58 \mathrm{ab}$ & $59.0 \mathrm{~b}$ & $2.43 \mathrm{a}$ & $1.44 \mathrm{a}$ & $55.4 \mathrm{~b}$ & $2.14 \mathrm{~b}$ & I. $18 \mathrm{~b}$ \\
\hline Guinea & $68.6 \mathrm{a}$ & $2.35 \mathrm{~b}$ & $1.49 \mathrm{bcd}$ & $63.1 \mathrm{a}$ & $2.40 \mathrm{ab}$ & $1.51 \mathrm{a}$ & $59.2 \mathrm{a}$ & $2.30 \mathrm{a}$ & $1.36 \mathrm{a}$ \\
\hline Standard deviation & 3.06 & 0.46 & & 3.18 & 0.13 & & 3.36 & 0.11 & \\
\hline
\end{tabular}

'Means per harvest interval.

${ }^{2}$ Means in the same column followed by one or more letters in common do not differ significantly at the 5\% probability level. 
fed as the only energy source. On the basis of this information, hay was graded from 1 to 5 when RNV ranged from 1.40 to 0.83 (9). In a draft report hay classification standards for Puerto Rico were formulated, by a designated committee. On the basis of preliminary data (7). The grades suggested were PR 1, 2, 3, and 4 corresponding to RNV 1.20, 1.19 to $0.99,0.98$ to 0.80 and 0.80 , respectively. The mean RNV obtained in this study were 1.55, 1.39 and 1.23 for the forages harvested at 35-, 45- and $55-\mathrm{DI}$, respectivley (table 2). RNV ranged from 1.81 on Coastcross harvested at 35-DI to 1.08 on Callie harvested at 55-DI. At 45- and 55-DI, guinea provided the highest valnes of RNV. On the basis of proposed local grades, the hays utilized in this study could be graded between PR 2 and PR 1. The most important factors to be considered upon deciding which forage species to use for hay production are yield performance and RNV. Star grass, Coastcross and slenderstem provided the best RNV at the 35-DI; guinea, Star grass and Coasteross were the best at 45-DI; and guinea and Coastcross were best at the 55-day cutting interval.

On the basis of yield performance, nutritive value, and crude protein content, the 45-day harvesting interval was the best overal for hay production among all of the species studied. All factors considered, guinea, stargrass and slenderstem harvested at $45-\mathrm{DI}$ can be recommended as the best alternatives presently available for hay production under conditions of irrigation and high fertilizer application in Vertisol soils on the south coast of Puerto Rico.

\section{RESUMEN}

Rendimiento y valor nutritivo del heno de 5 yerbas tropicales a 3 intervalos de corte

En un suelo Vertisol en la zona suroeste de Puerto Rico se sembraron cinco gramíneas forrajeras: Cynodan dactylon (Cross 1), Cynodon nlemfuensis (estrella), Cynodon plectostachyus (Callie), Digitaria pentzii (pangola fina), y Panicum maximum (guinea, PRPI 12917); se cosecharon a intervalos de 35,45 y 55 días y el forraje se henificó. Los rendimientos más altos de heno se obtuvieron con guinea a intervalos de 35 y 45 días (2069 y 2901 $\mathrm{kg}$./ha./corte, respectivamente), pero al intervalo de $\mathbf{5 5}$ días pangola fina produjo más (3397 kg./ha./corte). El contenido más alto en proteina bruta se obfuvo con estrella al intervalo de 35 días $(18.6 \%)$ y en Callie a los intervalos de 45 y 55 días (14.0\% y $11.5 \%$, respectivamente). El rendimiento en proteína bruta a intervalo de 35 días fue más elevado en estrella (336 kg./ho./corte) y a los intervalos de 45 y 55 días lo fueron en pangola fina (383 y $384 \mathrm{~kg}$./ha./corte, respectivamente). El coeficiente de digestión (DC) más alto al intervalo de 35 días se obtuvo con Cross $1(64,3)$. A los intervalos de 45 y 55 días, el DC más alto se obłuvo con guinea (63.0 y 59.0, respectivamente), pero al compararlos con los de pangloa fina y Cross 1 la diferencia no fue significativa. El consumo voluntario mayor a intervalo de 35 días se obtuvo en Cross 1 (2.82\% de peso vivo diariamente 
(PV), pero las diferencias no fueron signiticativas ni con pangola fina ni con estrella. A los intervalos de $\mathbf{4 5}$ y $\mathbf{5 5}$ días el consumo voluntario más alfo fue con estrella y guinea (2.43 y $2.30 \%$ PV, respectivamente). El valor nutrifivo relativo más alto (digestibilidad $\times$ consumo voluntario) se obtuvo con Cross 1 (1.81) a intervalos de 35 días, y con guinea a intervalos de 45 y 55 días (1.51 y 1.36, respectivamente). A base de los factores estudiados, guinea, estrella y pangola de talla fino, cosechadas a intervalos de $\mathbf{4 5}$ días, son las mejores para la producción de heno con riego y abonamiento adecuado en suelos Vertisol en la costa sur de Puerto Rico.

\section{LITERA'TURE (ITED)}

1. A. O. A. C. 1980. Official Methods of Analyses, Assoc. Off. Agric. Chem., Washington, D.C.

2. Arroyo-Aguilu, J. A. and J. A. Oporta-Téllez, 1980. Chemical composilion and in vivo nutrient digestibility of guinea and merker grass hays. J. Agric. Univ. P. R. 64: 294.

3. Cáceres, O. and J. I. Hernánde\%, 1981. Caraclerísticas henificativas de seis pastos destacados. Pastos y Forrajes. Rev. Esta. Exp. "Indio Hatuey," Perico, Matanzas, Cuba, 4 (3): 359-71.

4. Gutiérrez-Vargas, R., J. A. Arroyo-Aguilú and A. Ramírez-Ortiz, 1978. Voluntary intake, chemical composition and nutrient digestibility of pangolagrass and stargrass hays. J. Agric. Unive. P. R. 62: 389.

5. Harris, L. E., 1973. Chemical and Biologieal Methods for Feed Analysis. Center for Tropical Agriculture, Univ. Fla., Gainesville, Fla.

6. Machado, R. y J. Pedraza, 1981. Comportamiento inicial de gramíneas y leguminosas en la provincia Habana. Pastos y Forrajes. Rev. Estu. Exp. "Indio Hatuey," Perico, Matanzes, Cuba, 4 (3): 279-89.

7. Randel, P. F., J. A. Arroyo-Aguilú, A. V. Méndez-Cruz, J. Vélez-Santiago and B. Salas-Herrero, 1981. Estándares de calidad para la clasificación de heno en Puerto Rico. Borrador sometído por el comité designado por la Estación Experimental Agricola, Universidad de Puerto Rico.

8. Reid, J. T., 1973. Hay quality. In: Forages, The Seience of Grassland Agriculture. M. E. Heath, D. S. Metealfe, and R. E. Barnes (Eds), Iowas State University Press.

9. Rivera, R. and J. Rodriguez, 1980. Forage yield of fine grass under intensive grazing management in the humid region of Puerto Rico. J. Agric. Univ. P. R. 64: 259.

10. Roheweder, D. A., R. F. Barnes and N. Jorgensen, 1978. Proposed hay grading standard based on laboratory analyses for evaluating quality. J. Anim. Sci. 47: 747.

11. Román-García, F., J. A. Arroyo-Aguilú, H. Cestero and D. Rivera-Anaya. 1979. The feeding of dairy calves with pangola and stargrass hays. J. Agric. Umiv. P. R. 63:87.

12. Schank, S. C., O. C. Ruelke, W. R. Ocumpaugh, J. E. Moore and D. W. Hall, 1982. Survenola digitgrass, a tropical forage grass. Circ. Fla. Agric. Exp. Stn, No. 2-292.

13. Soldevila-Martínez, M., J. Vélez-Santiago, A. V. Méndez-Cruz and D. Jiménez-Tosado, 1979. Manejo y Utilización de los forrajes en Puerto Rico. Publicación 125, GT1: 19.

14. Steel, R. and J. H. Torrie, 1980. Principles and Procedures of Statisties. MeGraw Hill Book Co., New York.

15. Vélez-Santiago, J., A. Sotomayor-Ríos, S. Tores-Rivera and A. V. Méndez-Cruz, 1982. Performance of six Cenchrus and four Panicum forage grasses under cutting management in the Lajas Valley of Puerto Rico. J. Agric. Uniu. P. R. 66: 268.

16. Yazman, J. A., J. A. Arroyo-Aguilú, R. E. McDowell, I.J. Van Soest and H. Cestero, 1977. Voluntary intake and apparent digestibility of artificially dried stargrass fed to Holstein bull calves. J. Agric. Vhriv. P. R. 61: 429. 